\title{
High expression of disabled homolog 2-interacting protein contributes to tumor development and proliferation in cutaneous squamous cell carcinoma
}

\author{
Shao-Ping Yuan ${ }^{1,2 \#}$, Chang-Xing Li ${ }^{3 \#}$, Si Qin ${ }^{1,2 \#}, \mathrm{Ju} \mathrm{Wen}^{1,2}$, Xi-Bao Zhang ${ }^{4}$, Xin Tian ${ }^{4}$, Chao-Ying Zhu ${ }^{5}$, \\ Ting $\mathrm{Li}^{1,2}$, Jin-Ping Huang ${ }^{2}$, Xiao-Huan Zheng ${ }^{6}$ \\ ${ }^{1}$ The Second School of Clinical Medicine, Southern Medical University, Guangzhou, China; ${ }^{2}$ Department of Dermatology, Guangdong Second \\ Provincial General Hospital, Guangzhou, China; ${ }^{3}$ Department of Dermatology, Nanfang Hospital, Southern Medical University, Guangzhou, China; \\ ${ }^{4}$ Guangzhou Institute of Dermatology, Guangzhou, China; ${ }^{5}$ Guangzhou Panyu Station for Chronic Disease Control, Guangzhou, China; ${ }^{6}$ Nanhai \\ District People's Hospital, Foshan, China \\ Contributions: (I) Conception and design: SP Yuan, CX Li, S Qin; (II) Administrative support: J Wen; (III) Provision of study materials or patients: SP \\ Yuan, CX Li, S Qin, JP Huang, XH Zheng; (IV) Collection and assembly of data: XB Zhang, X Tian, S Qin, CY Zhu, T Li; (V) Data analysis and \\ interpretation: SP Yuan, CX Li, S Qin; (VI) Manuscript writing: All authors; (VII) Final approval of manuscript: All authors. \\ \#These authors contributed equally to this work. \\ Correspondence to: Dr. Ju Wen. Guangdong Second Provincial General Hospital, No. 466 Xin'gangzhong Road, Haizhu District, Guangzhou, China. \\ Email: wenju3139@163.com.
}

Background: Disabled homolog 2-interacting protein (DAB2IP), a Ras GTPase-activating protein, is downregulated in several cancers. Its depletion is involved in tumor cell proliferation, apoptosis, and metastasis, as well as epithelial-mesenchymal transition. The present study aimed to explore the potential role of DAB2IP in cutaneous squamous cell carcinoma (cSCC) and provide a theoretical basis for the diagnosis and targeted therapy of cSCC.

Methods: The clinicopathological features of DAB2IP expression in cSCC were analyzed by immunohistochemistry, and the effects of DAB2IP on SCL-1 cell behavior were determined via genetic interference in vitro. SCL-1 cell lines that exhibited reduced expression of DAB2IP and a scrambled shRNA control were constructed using a lentivirus vector-based shRNA technique. RNA extraction, reverse transcription-quantitative PCR (RT-qPCR), MTT assay, colony formation test, cell cycle analysis, apoptosis test, transwell assay, wound-healing assay, in vitro invasive assay were used in this study.

Results: The immunohistochemical results demonstrated that the expression of DAB2IP was higher in cSCC tissues than in soft fibroma. The level of DAB2IP expression was associated with the degree of malignancy and the depth of tumor infiltration; however, it had no association with patients' sex, tumor size, location, or phenotype. The results of the MTT, cell cycle, apoptosis, and invasion experiments demonstrated that knockdown of DAB2IP inhibited the viability and invasion of SCL-1 cells in vitro.

Conclusions: High expression of DAB2IP may contribute to the development and proliferation of cSCC.

Keywords: Cutaneous squamous cell carcinoma (cSCC); disabled homolog 2-interacting protein (DAB2IP); immunohistochemistry; SCL-1; proliferation; invasion

Submitted Jun 01, 2020. Accepted for publication Sep 02, 2020.

doi: 10.21037/atm-20-5067

View this article at: http://dx.doi.org/10.21037/atm-20-5067 


\section{Introduction}

Cutaneous squamous cell carcinoma (cSCC) is the second most common skin cancer, typically occurring in the skin, mucous membranes and cutaneous appendages. Most SCCs occur in the epidermis or mucosa covered with squamous epithelium (1). Ultraviolet radiation, advanced age and immunosuppression are considered as the common risk factors for cSCC. The majority of patients with cSCC are cured by surgery. A small percentage of patients with advanced cSCC, suffering incurable situation (like the tumor becomes metastatic or has locally advanced progression) are no longer indications for surgery or radiation therapy. In this condition, the palliative systemic therapy is considered as part of routine clinical practice (2). Despite many therapies, including surgery, allowing for the effective removal of the tumor, the rates of metastasis and recurrence among cSCC patients are approximately $5 \%$ and $8 \%$, respectively (3). Notably, cSCCs account for the majority of non-melanoma skin cancer (NMSC) deaths (4). The high incidence and high risk of metastasis and recurrence highlight the importance of finding a more effective treatment for patients with cSCC. Characterized by malignant proliferation of epidermal keratinocytes, cSCC is usually caused by ultraviolet radiation or the malignant transformation of actinic keratosis or Bowen's disease. However, the specific molecular pathogenesis of cSCC is far from being understood (5).

Disabled homolog 2 interacting protein (DAB2IP) is a member of the Ras GTPase-activating protein family located at chromosome 9q33.1-q33.3, which negatively regulates the Ras-mediated signaling pathway through interacting with the $\mathrm{N}$-terminal domain of the DAB2 protein (6). The downregulation of DAB2IP was first found in prostate cancer cells (7). Recent studies on DAB2IP have focused on its function and molecular mechanisms in prostate cancer, hepatocellular carcinoma (8), pancreatic cancer (9), and gastric cancer $(10,11)$. These studies have suggested that it may be a tumor suppressor gene involved in the inhibition of cell proliferation, apoptosis, epithelialmesenchymal transition (EMT), and tumor metastasis, and that it may predict cancer risk based on single-nucleotide polymorphisms. However, the role of DAB2IP in skin tumors has yet to be reported. Therefore, this study aimed to identify the molecular DAB2IP-related mechanisms in the occurrence of cSCC, to provide a theoretical basis for novel treatments of cSCC.

We present the following article in accordance with the MDAR reporting checklist (available at http://dx.doi. org/10.21037/atm-20-5067).

\section{Methods}

\section{Clinical data}

This study enrolled 48 patients with cSCC who were surgically treated in the Department of Dermatology of the Guangdong Second Provincial General Hospital, (Guangzhou, China) and the Guangzhou Institute of Dermatology (Guangzhou, China) between January, 2012, and November, 2017 (clinical trial registration number: ChiCTR2000038327).

Inclusion criteria:

(I) Patients who suffer from CSCC.

(II) First onset without any treatment before.

Exclusion criteria:

(I) Patients who have undergone gene therapy, radiotherapy, or chemotherapy or immunotherapy.

(II) Patients who suffer from other skin disease at the same time.

The patients had an average age of $66 \pm 18.50$ (range, 26 to 91 ) years; 26 patients were male (age range, 26 to 89 years) and 22 patients were female (age range, 32 to 91 years). The patients' complete clinical data were collected and are shown in Tables 1 and 2. The cSCC tissues were histologically classified by three pathologists in a double-blinded manner according to the following criteria (12): (I) Grade I: undifferentiated squamous cell carcinoma accounts for $<25 \%$ (generally does not metastasize); (II) Grade II, undifferentiated squamous cells account for 25-50\%; (III) Grade III, a large number of undifferentiated squamous cells (50-75\%); and (IV) Grade IV (>75\% of undifferentiated cells).

In addition, 26 soft fibroma tissues collected from 26 patients without cSCC served as the control group; these patients were treated in the Department of Dermatology in the Sixth People's Hospital of Dongguan in 2017 and included 15 male and 11 female patients whose ages ranged between 30 and 65 years and between 30 and 55 years, respectively.

The study was approved by the Guangdong Second Provincial General Hospital Ethical Committee (approval no. 2019-PFKWZ-004). All procedures performed in this study involving human participants were in accordance with the Declaration of Helsinki (as revised in 2013). All patients signed informed consent for surgery when sample collection 
Table 1 Clinical data of the patients involved in the present study

\begin{tabular}{lcc}
\hline Group & cSCC & Benign dermal vegetation \\
\hline Total cases & 48 & 26 \\
Sex & & \\
Male & 26 & 15 \\
Female & 22 & 11 \\
Age range (years) & $26-91$ & $30-65$ \\
Male & $26-89$ & $30-65$ \\
Female & $32-91$ & $30-55$ \\
Average age (years) & $66 \pm 18.50$ & $43 \pm 9.07$ \\
\hline
\end{tabular}

cSCC, cutaneous squamous cell carcinoma.

took place. All patients agreed for their samples to be used in scientific research.

\section{Immunohistochemistry (IHC)}

All samples obtained from the 48 cSCC patients and 26 soft fibroma patients were fixed in $10 \%$ formalin for $24 \mathrm{~h}$ at room temperature and embedded in paraffin. The paraffin-embedded tissues were serially cut into 5 - $\mu \mathrm{m}$ sections and heated in an oven at $60 \pm 5{ }^{\circ} \mathrm{C}$ for $2 \mathrm{~h}$. The tissue sections were dewaxed, antigen-repaired according to the instructions and operation method of the $50 x$ Antigen Repair Solution (cat. no. GT100411; Shanghai GeneTech Co., Ltd., China), soaked in $3 \% \mathrm{H}_{2} \mathrm{O}_{2}$ for $8 \mathrm{~min}$ at room temperature, and washed with running water. After antigen repair, the sections were rinsed with PBS, dried at room temperature, and incubated with a primary rabbit anti-DAB2IP polyclonal antibody (1:800; cat. no. ab87811; Abcam) for $18-24 \mathrm{~h}$ at $4{ }^{\circ} \mathrm{C}$. The sections in incubation box was placed at room temperature for $30 \mathrm{~min}$ and then were rinsed with PBS 3 times for 2 minutes. The excess PBS was removed, and the secondary goat anti-rabbit IgG H\&L (HRP) (cat.no.ab205718; Abcam) was added before incubation at $37{ }^{\circ} \mathrm{C}$ for $30 \mathrm{~min}$. DAB Color-substrate solution was added for 3$5 \mathrm{~min}$, followed by rinsing with running water for 5 $10 \mathrm{~min}$ to stop the color development. Then, the tissue sections were counterstained with hematoxylin for $1 \mathrm{~min}$ and differentiated with $0.5 \%$ hydrochloric alcohol for 3 seconds. The sections were dehydrated and mounted for microscopic examination at room temperature. The signal was visualized with 3,3'-diaminobenzidine tetrachloride
(Leica Microsystems $\mathrm{GmbH}$ ), and the staining scores were independently examined by two clinical pathologists. Light microscopy (Olympus BX43; Olympus Corporation) of five random regions (magnification, $\times 200$ ) was performed, and the presence of brown granules in the cytoplasm was considered a positive signal.

\section{Evaluation of staining}

The percentage of positive cells in each field of vision was independently determined by two pathologists using the double-blinded method. The percentage of positive cells observed was scored as: $0-5 \%$ [0]; 6-25\% [1]; 25-50\% [2]; $51-75 \%$ [3]; or $75-100 \%$ [4]. The staining intensity was scored as follows: no staining, 0; pale yellow, 1; brown yellow, 2; or dark yellow/tan, 3. The total DAB2IP immunostaining score was calculated as the sum of the scores for percent positivity and the staining intensity. DAB2IP staining was evaluated as follows: final staining scores of 0 and 1 were considered negative (-); 2 and 3 were considered weakly positive $(+) ; 4$ and 5 were considered moderately positive (++); and 6 and 7 were considered strongly positive (+++). This scoring method is consistent with that described by Fromowitz et al. (12). A final staining score of - or + was classified as low DAB2IP expression, whereas ++ or +++ was classified as high DAB2IP expression.

\section{Cell culture}

The human cSCC SCL-1 cell line (RRID: CVCL_A78, Guangzhou Jennio Biotech Co., Ltd, China.) was purchased from the Cell Bank of the Chinese Academy of Sciences and cultured in Dulbecco Eagle's Minimum Essential Medium (DMEM) containing 10\% fetal bovine serum (FBS; Gibco; Thermo Fisher Scientific, Inc., USA), $100 \mathrm{U} / \mathrm{mL}$ penicillin G sodium, and $100 \mu \mathrm{g} / \mathrm{mL}$ streptomycin sulfate (Gibco; Thermo Fisher Scientific, Inc.). The cells were maintained at $37^{\circ} \mathrm{C}$ in a humidified atmosphere containing $5 \% \mathrm{CO}_{2}$.

\section{RNA interference (RNAi)}

SCL-1 cell lines that exhibited reduced expression of DAB2IP [knockdown (KD) group] and a scrambled shRNA control [negative control (NC) group] were constructed using a lentivirus vector-based shRNA technique. The sequences of the DAB2IP target gene and the lentivirus vector were as follows: DAB2IP-RNAi (64428-2), 
Table 2 Associations between clinical features and disabled homolog 2-interacting protein (DAB2IP) expression in cutaneous squamous cell carcinoma specimens

\begin{tabular}{|c|c|c|c|c|c|}
\hline Feature & $N$ & Low expression (--+) & High expression $(++-+++)$ & $x^{2}$ & $P$ value \\
\hline Sex & & & & 0.13 & $>0.05$ \\
\hline Male & 26 & 7 & 19 & & \\
\hline Female & 22 & 7 & 15 & & \\
\hline Age (years) & & & & 4.55 & $<0.05^{\mathrm{a}}$ \\
\hline$\geq 66$ & 30 & 12 & 18 & & \\
\hline$<66$ & 18 & 2 & 16 & & \\
\hline Location & & & & 1.32 & $>0.05$ \\
\hline Head/face/neck & 30 & 7 & 23 & & \\
\hline Torso/limbs/genitals & 18 & 7 & 11 & & \\
\hline Depth of infiltration & & & & 4.38 & $<0.05^{\mathrm{a}}$ \\
\hline Superficial-type & 23 & 10 & 13 & & \\
\hline Invasive-type & 25 & 4 & 21 & & \\
\hline Size & & & & 2.96 & $>0.05$ \\
\hline$\geq 2 \mathrm{~cm}$ & 25 & 10 & 15 & & \\
\hline$<2 \mathrm{~cm}$ & 23 & 4 & 19 & & \\
\hline Phenotype & & & & 0.01 & $>0.05$ \\
\hline Erythema-ulcer type & 21 & 6 & 15 & & \\
\hline Non-ulcer type & 27 & 8 & 19 & & \\
\hline Clinical stage & & & & 10.76 & $<0.05^{\mathrm{a}}$ \\
\hline$|-| \mid$ & 27 & 13 & 14 & & \\
\hline III-IV & 21 & 1 & 20 & & \\
\hline \multicolumn{6}{|l|}{ Metastasis } \\
\hline Yes & 0 & & & & \\
\hline No & 48 & & & & \\
\hline Recurrence & & & & 0.24 & $>0.05$ \\
\hline Yes & 3 & 0 & 3 & & \\
\hline No & 45 & 14 & 31 & & \\
\hline
\end{tabular}

${ }^{a}, P<0.05$.

\section{5'-ATGGTGATTGAGAACGATCTT-3'; DAB2IP-RNAi} (64429-1), 5'-TGCCTGGACGATGTGCTCTAT-3'; DAB 2 IP - RNAi (64430 - 1), 5 ' - TGGCAGCAA GGAGGAATACAT-3'; GV248, 5'-hU6-MCS-UbiquitinEGFP-IRES-puromycin-3'; scrambled sequence, 5'-TTCTCCGAACGTGTCACGT-3'. The vector was coupled with the target gene sequence to form the
DAB2IP-RNAi(s) inverter lentivirus, and the sequences were as follows: PSC64428-2 (KD1), ccggATGGTGATTG AGAACGATCTTttcaagagaAAGATCGTTCTCAATCAC CATttttg; PSC64429-1 (KD2), ccggTGCCTGGACGAT GTGCTCTATttcaagagaATAGAGCACATCGTCCAGG CAttttg; and PSC64430-1 (KD3), ccggTGGCAGCAAGG AGGAATACATttcaagagaATGTATTCCTCCTTGCTGC 
CAtttttg. Oligonucleotides were constructed in a lentiviral RNAi vector (Shanghai GeneChem Co., Ltd., China).

At $24 \mathrm{~h}$ before transfection, 293 T cells in the logarithmic growth phase were digested with trypsin, and the cell density was adjusted to $5 \times 10^{6}$ cells $/ 15 \mathrm{~mL}$ in DMEM containing $10 \%$ serum for subsequent transfection experiments. The serum-free medium was replaced $2 \mathrm{~h}$ before transfection. The DNA solutions (15 $\mu \mathrm{g}$ Helper 1.0, $10 \mu \mathrm{g}$ Helper 2.0, and $20 \mu \mathrm{g} G V$ vector plasmid carrying target gene sequence) were added into a sterilized centrifuge tube (Shanghai GeneChem Co., Ltd.). The same quantities of transfection reagent and GeneChem transfection reagent (Shanghai GeneChem Co., Ltd.) were mixed; the total volume was adjusted to $1 \mathrm{~mL}$ before incubation at room temperature for $15 \mathrm{~min}$. The mixture was slowly added to the $293 \mathrm{~T}$ cell culture medium, mixed, and cultured in an incubator with $5 \% \mathrm{CO}_{2}$ at $37{ }^{\circ} \mathrm{C}$. After $6 \mathrm{~h}$ of culture, the medium containing the transfection mixture was discarded and $10 \mathrm{~mL}$ PBS was added. The petri dish was gently agitated to wash the remaining transfection mixture and discarded, and $20 \mathrm{~mL}$ DMEM containing 10\% serum was added. The cells were cultured for $48-72 \mathrm{~h}$ at $37{ }^{\circ} \mathrm{C}$ with $5 \% \mathrm{CO}_{2}$. At $48 \mathrm{~h}$ post-transfection, the $293 \mathrm{~T}$ cell supernatant was collected. Cell fragments were removed by centrifugation at $4^{\circ} \mathrm{C}$ at $4,000 \times \mathrm{g}$ for $10 \mathrm{~min}$. The supernatant was filtered into a $40-\mathrm{mL}$ superspeed centrifugal tube with a $0.45 \mu \mathrm{m}$ filter. The samples were evenly distributed into the centrifuge tube, placed into a Beckman XE-90 ultracentrifuge (Beckman Coulter, Inc., USA), and centrifuged at 64,300 $\times \mathrm{g}$ for $2 \mathrm{~h}$ at $4{ }^{\circ} \mathrm{C}$. The supernatant was discarded, and the residual liquid on the tube wall was removed. The resuspension solution was made by adding virus preservation solution. After centrifugation at 11,200 $\times \mathrm{g}$ for $5 \mathrm{~min}$, the supernatant was separated and then the lentivirus-containing supernatant was obtained. SCL-1 cells (3-5 $\times 10^{4}$ cells $/ \mathrm{mL}$ ) were divided into the $\mathrm{KD} 1, \mathrm{KD} 2, \mathrm{KD} 3$, and $\mathrm{NC}$ groups, transfected with serial dilutions from the three above-mentioned lentiviral supernatants, and selected by $4 \mu \mathrm{g} / \mathrm{mL}$ puromycin with Resistance Gene Marker (American, Clontech) for 2 weeks. The virus dosages in the KD1, KD2, KD3, NC were 3.00, 1.50, 2.00, and 6.00, respectively, and the virus titers were $1 \mathrm{E}+9,2 \mathrm{E}+9,1.5 \mathrm{E}+9$, and $5 \mathrm{E}+8$, respectively. The $\mathrm{KD}$ group with the highest gene reduction rate was selected as the experimental group for subsequent experiments. The control (CON) group was the untransfected cell group.

\section{$R N A$ extraction and reverse transcription-quantitative PCR (RT-qPCR)}

Following transfection for $0,24,48$, and $72 \mathrm{~h}$, total RNA was extracted from the SCL-1 cells using TRIzol ${ }^{\circledR}$ reagent (Shanghai Pufei Biotechnology Co., Ltd., China), and cDNA was synthesized from $2 \mu \mathrm{g}$ RNA using the Promega M-MLV Synthesis kit (Promega Corporation) according to the manufacturer's instructions. Reverse transcription-quantitative polymerase chain reaction (RTqPCR) was performed using the two-step method with a MicroRNA PCR LightCycler 480 (Roche Diagnostics). The primers used were as follows: DAB2IP forward, 5 '-ACAGGGATAGGCTAAGGAGTAAG-3' and reverse, 5'-CTGGCACTTGAACAGGGTCTC-3' (final product size, $125 \mathrm{bp}$ ); GAPDH forward, 5'-TGACTTCAACAGCGACACCCA-3' and reverse, 5'-CACCCTGTTGCTGTAGCCAAA-3' (final product size, 121 bp). Glyceraldehyde 3-phosphate dehydrogenase $(\mathrm{GADPH})$ was used as an internal reference. The PCR conditions were: $15 \mathrm{sec}$ at $95^{\circ} \mathrm{C}$ (predenaturation), followed by 40 cycles of $5 \mathrm{sec}$ at $95^{\circ} \mathrm{C}$ (denaturation) and $30 \mathrm{sec}$ at $60{ }^{\circ} \mathrm{C}$ (annealing); the absorbance value was read at each extension stage. After thermocycling, the products were held for $1 \mathrm{~min}$ at $95^{\circ} \mathrm{C}$ (denaturation) and $1 \mathrm{~min}$ at $60{ }^{\circ} \mathrm{C}$ (cooling); each step was increased by $0.5^{\circ} \mathrm{C}$ for $30 \mathrm{sec}$ until $90{ }^{\circ} \mathrm{C}$ was reached, and an additional step of $65^{\circ} \mathrm{C}$ for $30 \mathrm{sec}$ was performed. The absorbance values were detected simultaneously. The $2^{-\Delta \Delta \mathrm{Cq}}$ method was used to calculate relative fold changes in mRNA expression (13).

\section{MTT assay}

Transfected cells in the logarithmic growth period were digested with pancreatic enzymes (Shanghai Chemical Reagent Co., Ltd.) to form a cell suspension in complete DMEM. After seeding into 96-well plates $\left(2 \times 10^{3}\right.$ cells/well; $100 \mu \mathrm{L}$ cell suspension/well), the cells were incubated for 24, 48, 72, 96, or $120 \mathrm{~h}$. MTT reagent $(20 \mu \mathrm{L} ; 5 \mathrm{mg} / \mathrm{mL}$; Beijing Dingguo Changsheng Biotechnology Co., Ltd., China) was added for $4 \mathrm{~h}$ until a formazan particle precipitate became visible. Precipitates were dissolved in $100 \mu \mathrm{L}$ dimethyl sulfoxide. The absorbance value of each well was detected at $490 \mathrm{~nm}$ with an enzyme standard instrument microplate reader. Each experiment was repeated in triplicate. 


\section{Colony formation test}

Cells $(\sim 800)$ were seeded into each well of a 6 -well culture plate. After 14 days of incubation at $37^{\circ} \mathrm{C}$, the cells were washed once with $\mathrm{PBS}$, fixed for $30 \mathrm{~min}$ at room temperature with $1 \mathrm{~mL} 4 \%$ paraformaldehyde, and rewashed with PBS. Subsequently, the cells were stained with $500 \mu \mathrm{L}$ Giemsa solution (Shanghai Ding Guo Biotechnology Co., Ltd., China) for 10-20 min at room temperature. Under a XDS-100 inverted microscope, the number of colonies containing $\geq 50$ cells was counted as follows: Clone formation efficiency $=$ (number of colonies / number of cells inoculated) $\times 100 \%$.

\section{Cell cycle analysis}

First, the cells were collected in a centrifuge tube and centrifuged for $5 \mathrm{~min}$ at room temperature at $256.8 \times \mathrm{g}$. The cell precipitate was washed with $4{ }^{\circ} \mathrm{C}$ D-Hanks' solution (Shanghai GeneChem Co., Ltd.). Next, the samples were centrifuged once more for $5 \mathrm{~min}$ at room temperature at $256.8 \times \mathrm{g}$ and washed with precooled $75 \%$ ethanol for $1 \mathrm{~h}$. Step 2 was then repeated. Following that, $1 \mathrm{~mL}$ of cell staining fluid consisting of $40 \times$ propidium iodide (PI; $2 \mathrm{mg} / \mathrm{mL}$; Sigma-Aldrich; Merck KGaA), 100X RNase (10 mg/mL; Fermentas; Thermo Fisher Scientific, Inc.), and 1× D-Hank's solution (ratio, 25:10:1,000) was added to the cell sediments. The fluorescence intensity of PI, which was proportional to the content of nucleic acid embedded, was detected using a flow cytometer. Cell cycle analysis was performed with ModFit LT 4.0 software (Verity Software House).

\section{Apoptosis test}

Cells $\left(\sim 1 \times 10^{5}\right.$ cells/well $)$ were plated into 6 -well plates and cultured for 5 days until they reached $\geq 85 \%$ confluence. The cells were resuspended in DMEM and collected in a centrifuge tube. The centrifugation steps were as follows: centrifugation at $256.8 \times \mathrm{g}$ for $5 \mathrm{~min}$ at room temperature; the cell precipitate was washed with $4{ }^{\circ} \mathrm{C}$ precooled D-Hank's solution and $1 \times$ binding buffer from the Annexin V Apoptosis Detection Kit APC (eBioscience; Thermo Fisher Scientific, Inc.); centrifugation at $256.8 \times$ g for $3 \mathrm{~min}$ at room temperature; and the cells were collected. The cells collected in the early stage of apoptosis were resuspended with $20 \mu \mathrm{L}$ of $1 \times$ binding buffer and stained with $10 \mu \mathrm{L}$ Annexin V (eBioscience; Thermo Fisher Scientific, Inc.).
Additionally, $500 \mu \mathrm{L}$ of $1 \times$ binding buffer was added for the flow cytometric (EMD Millipore) detection of the fluorescence intensity of Annexin V, which was proportional to the phosphatidylserine content on the surface of the cell membrane. Cell cycle analysis was performed with Guava EasyCyte HT Incyte 3.1 (EMD Millipore).

\section{Transwell assay}

A 24-well plate was equipped with polyethylene terephthalate (PET) membrane Transwell chambers (Corning, Inc.) with a pore size of $8 \mathrm{~mm}$. Serum-free medium $(100 \mu \mathrm{L})$ was added to the upper compartment of the chamber and incubated for $1 \mathrm{~h}$ at $37^{\circ} \mathrm{C}$. The medium in the upper compartment was removed, then $100 \mu \mathrm{L}$ of the cell suspension $\left(1 \times 10^{5}\right.$ cells/well $)$ was added to the upper compartment, and $600 \mu \mathrm{L}$ of medium containing $30 \%$ FBS was added as the chemotactic factor to the lower compartment. Each cell group was plated in three duplicate wells. Following $24 \mathrm{~h}$ of incubation, the extra medium was removed with absorbent paper, and the noninvasive cells were removed with a cotton swab. Cells that had migrated through the membrane and had attached to the lower surface of the membrane were fixed with $4 \%$ polyformaldehyde for $30 \mathrm{~min}$ and stained with Giemsa solution for $3 \mathrm{~min}$ at room temperature. Cells that had migrated to the lower compartment of the chamber were counted under a light microscope in five random visual fields (×200 magnification) as migratory cells per field.

\section{Wound-healing assay}

Cells $\left(5 \times 10^{4}\right.$ cells/well $)$ were seeded into each well of a $96-$ well plate and allowed to reach $>90 \%$ confluence, upon which, low-concentration serum medium was added, and a wound was created across the diameter of the well with a 1-mL pipette tip. Then, the cells were washed twice with serum-free medium and incubated in DMEM/F-12 (Corning, Inc.) medium containing $0.5 \% \mathrm{FBS}$ at $37{ }^{\circ} \mathrm{C}$ with $5 \% \mathrm{CO}_{2}$. At 0,4 , and $8 \mathrm{~h}$ of incubation, a fluorescence microscope (Olympus Corporation) was used to capture phase-contrast images at $\times 50$ magnification. The percentage of the area covered by migrated cells (wound recovery) relative to $0 \mathrm{~h}$ was calculated as an indication of the migration ability.

\section{In vitro invasive assay}

The Corning ${ }^{\circledR}$ BioCoat $^{\mathrm{TM}}$ Matrige $^{\circledR}$ Invasion Chamber 
A B

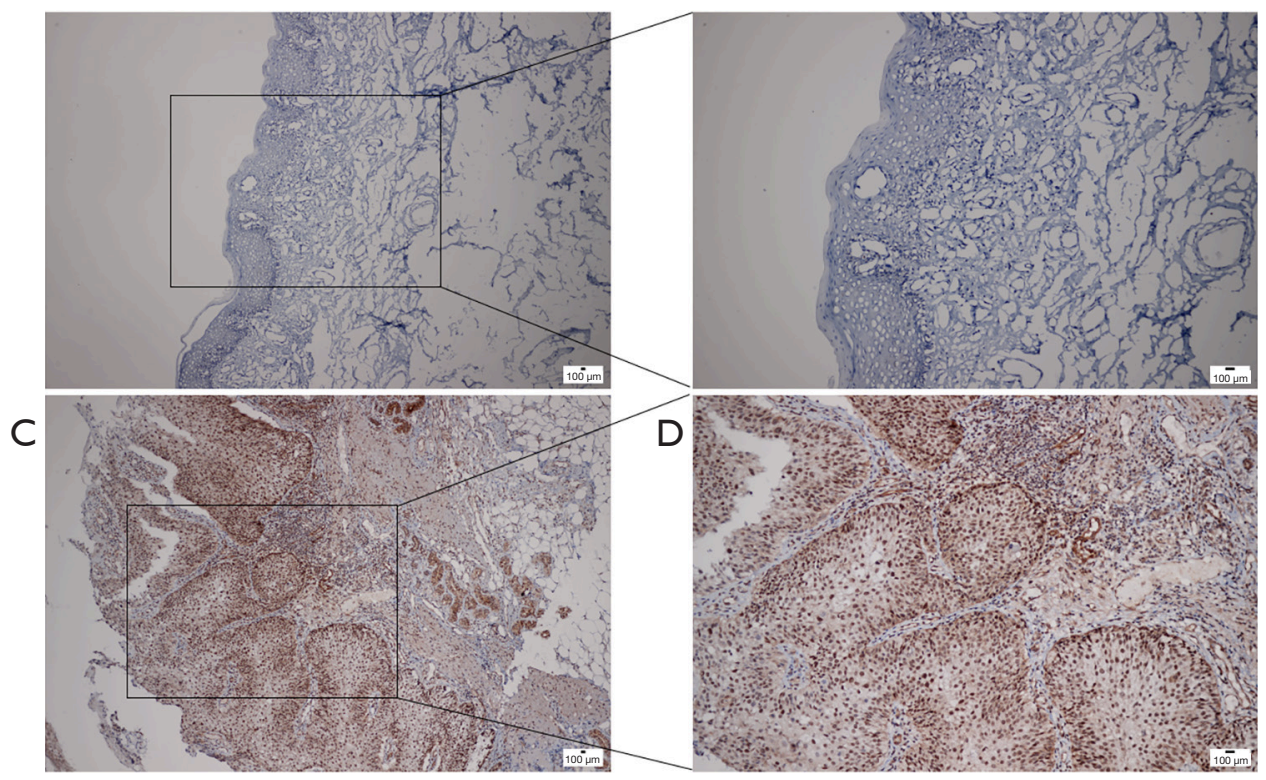

Figure 1 Immunohistochemical and hematoxylin staining of DAB2IP protein expression in benign dermal vegetation and cutaneous squamous cell carcinoma. (A,B) Benign dermatitis tissue with weak positive or no expression. Magnification, (A) $\times 100,($ B) $\times 200$. (C,D) Cutaneous squamous cell carcinoma tissue. The majority of the tumor cells were stained pale brown to brown, with a small number of unstained cells in between; DAB2IP exhibited positive expression. Magnification, (C) $\times 100$, (D) $\times 200$. DAB2IP, disabled homolog 2-interacting protein.

(Corning, Inc.) composed of 24-well tissue culture plates and 12 inserts with 8 - $\mu \mathrm{m}$ pores in a PET membrane coated with Matrigel (Corning, Inc.) were used. The Matrigel was rehydrated by adding serum-free medium $(500 \mu \mathrm{L})$ to the upper and lower chambers, followed by incubation at $37^{\circ} \mathrm{C}$ for $2 \mathrm{~h}$. The chamber was transferred to a new orifice plate, and the medium in the upper compartment was removed. A total of $500 \mu \mathrm{L}$ cell suspension $\left(1 \times 10^{5}\right.$ cells/well $)$ was added to the upper compartment, and $750 \mu \mathrm{L} \mathrm{30 \%} \mathrm{FBS} \mathrm{medium}$ was added to the lower compartment as the chemotactic factor. Each cell group was plated in three duplicate wells. Following incubation at $37^{\circ} \mathrm{C}$ for $40 \mathrm{~h}$, the medium was removed with absorbent paper, and a cotton swab was used to remove noninvasive cells. Cells that had migrated through the membrane and attached to the lower surface of the membrane were stained with Giemsa solution at room temperature for $5 \mathrm{~min}$ and counted under a light microscope in five random visual fields ( $\times 200$ magnification).

\section{Statistical analysis}

All data were entered in Epidata 3.0 (14), and SPSS 21.0
(IBM Corporation) was used to perform all statistical analyses. The $\chi^{2}$ test was used to evaluate the associations between DAB2IP expression and various clinicopathological parameters. In vitro proliferation and invasion assays were analyzed using one-way analysis of variance (ANOVA). $\mathrm{P}<0.05$ was considered to indicate a statistically significant difference.

\section{Results}

\section{Expression analysis of DAB2IP in cSCC tissues}

The expression of DAB2IP in 48 surgical specimens of cSCC and 26 surgical specimens of soft fibroma of the skin was examined by IHC. DAB2IP protein was mainly located in the cytoplasm of cSCC cells or in cells in the basal cell layer. The expression of DAB2IP in cSCC tissues was notably higher than that in benign dermal vegetation (Figure 1). The positive rate of DAB2IP protein in benign dermal vegetation was $42.3 \%$, which was significantly decreased compared with that in cSCC tissues $(85.4 \%$; $\mathrm{P}<0.05$; Table 3). Table 2 summarizes the associations between clinicopathologic features and DAB2IP expression 
Table 3 Expression of DAB2IP in cSCC and normal tissues

\begin{tabular}{lccccccc}
\hline \multirow{2}{*}{ Group } & \multicolumn{3}{c}{ DAB2IP EXPRESSION } & Total & Positive rate & $\chi^{2}$ & P value \\
\cline { 2 - 6 } & - & + & ++ & +++ & & $85.40 \%$ & 15.00 \\
\hline cSCC and Bowen's disease & 7 & 7 & 10 & 24 & 48 & $<.01$ \\
Benign dermal vegetation & 15 & 3 & 2 & 6 & 26 & $42.30 \%$ \\
Total & 22 & 10 & 12 & 30 & 74 & $70.27 \%$ \\
\hline
\end{tabular}

DAB2IP, disabled homolog 2-interacting protein; cSCC, cutaneous squamous cell carcinoma.

in cSCC. Among the 48 cases of cSCC tissues, 34 (70.8\%) exhibited high DAB2IP expression, whereas the other 14 cases $(29.2 \%)$ had low DAB2IP expression (Table 2). DAB2IP expression was positively associated with age, depth of infiltration, and clinical stage $(\mathrm{P}<0.05$; Table 2). However, no significant associations were identified between DAB2IP expression and sex, tumor size, location, or clinical phenotype (Table 2). These results suggested that increased DAB2IP expression may be associated with the development of cSCC.

\section{shRNA targeting DAB2IP inbibits DAB2IP $m R N A$ expression}

DAB2IP expression was stably knocked down using a lentiviral vector-based RNAi technique in the SCL-1 cSCC cell line. Three lentiviral vectors were used to produce $\mathrm{KD} 1, \mathrm{KD} 2$, and $\mathrm{KD} 3$ cells, and the knockdown efficiency was confirmed by fluorescence and RT-qPCR analysis (Figure 2). The relative expressions of the DAB2IP gene in the KD1, KD2, and KD3 groups were $0.476 \pm 0.063$, $0.443 \pm 0.073$, and $0.129 \pm 0.026$, respectively, whereas in the NC group, relative expression was $1.005 \pm 0.004$ (Tables 4,5). Compared with the NC group, the knockdown efficiency of the DAB2IP gene was $52.4 \% \pm 6.3 \%$ in the $\mathrm{KD} 1$ group $(\mathrm{P}<0.05), 55.7 \% \pm 7.3 \%$ in the $\mathrm{KD} 2$ group $(\mathrm{P}<0.05)$, and $87.1 \% \pm 2.6 \%$ in the KD3 group $(\mathrm{P}<0.05)$. Consequently, KD3 cells were used as the experimental group in the subsequent experiments.

\section{Effect of DAB2IP silencing on the cellular viability of $S C L-1$ cells in vitro}

To further determine the role of DAB2IP in cSCC, a series of in vitro cell experiments were carried out to observe the viability and invasive ability of the cells following DAB2IP knockdown. In the MTT colorimetric assay, CON and $\mathrm{NC}$ cells were used as the control groups. The absorption of $490 \mathrm{~nm}$ light with time was recorded in the KD group and control group, respectively. Figure 3 shows that the absorption of $490 \mathrm{~nm}$ light significantly lower in the KD group than in the CON and NC groups, which suggests that knockdown of DAB2IP resulted in a reduced rate of increase in the proliferation rate of $\mathrm{KD}$ cells compared with that of the control cells $(\mathrm{P}<0.05$; Figure 3). The results of the cell cloning experiment indicated that the number of sub-clones in the KD group was significantly lower than that in the CON and NC groups (Figure 4).

\section{Effect of DAB2IP silencing on the cell cycle and apoptosis of SCL-1 cells in vitro}

Cell cycle analysis was also performed to identify the cell cycle stage that was affected by DAB2IP. A cell cycle test revealed that the $\mathrm{KD}$ subclone incorporated more PI than the $\mathrm{NC}$ subclone $(\mathrm{P}<0.05$; Figure 5$)$, which indicated that knockdown of DAB2IP reduced the number of cells in the $\mathrm{S}$ phase. Moreover, flow cytometry analysis (Figure 6) revealed that DAB2IP knockdown decreased the percentage of cells in the S phase (during which DNA is synthesized), which suggested that DAB2IP depletion may inhibit the duplication of cell genetic materials. These data also suggested that DAB2IP knockdown inhibited cell proliferation by affecting the $\mathrm{S}$ phase of the cell cycle. Furthermore, DAB2IP knockdown significantly promoted apoptosis $(\mathrm{P}<0.05$; Figure 6).

\section{The effect of DAB2IP silencing on the migratory ability of SCL-1 cells in vitro}

The effects of DAB2IP expression on the migratory ability of SCL-1 cells was analyzed with Transwell and wound healing assays. The results of the Transwell assay revealed that the number of migrated KD cells was significantly lower compared with that of the control cells $(\mathrm{P}<0.05$; Figure 7$)$. Meanwhile, the wound healing assay 

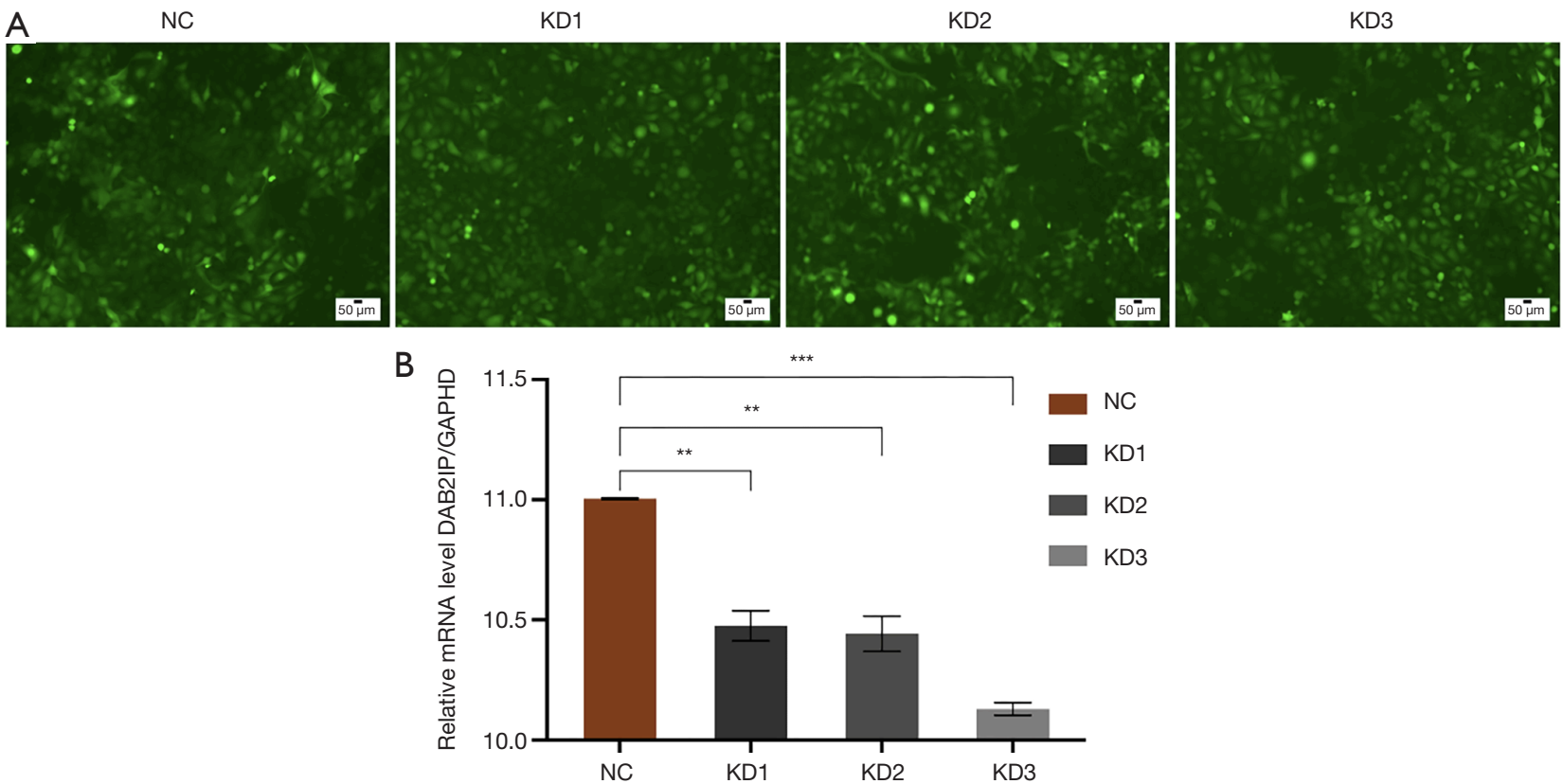

Figure 2 DAB2IP knockdown efficiency. (A) Green fluorescence in SCL-1 cells transfected with the DAB2IP-RNA interference lentivirus. Magnification, $\times 200$. (B) The levels of DAB2IP mRNA expression were detected in wild-type cells and in cells with stable knockdown of DAB2IP by reverse transcription-quantitative polymerase chain reaction in KD1, KD2, and KD3 SCL-1 cells. The bar graphs represent the DAB2IP mRNA levels normalized to GADPH. Error bars represent the standard error of the mean (SEM; N=3). Statistical significance was determined by one-way analysis of variance (ANOVA). DAB2IP, disabled homolog 2-interacting protein; NC, negative control group; KD, knockdown of DAB2IP. **, $\mathrm{P}<0.01 ;{ }^{* * *}, \mathrm{P}<0.001$.

Table 4 Summary of relative expression of target genes in three repetitive experiments

\begin{tabular}{lccc}
\hline Sample & Infection duplication 1 & Infection duplication 2 & Infection duplication 3 \\
\hline NC & 1.002 & 1.009 & 1.003 \\
KD1 & 0.533 & 0.486 & 0.409 \\
KD2 & 0.525 & 0.417 & 0.386 \\
KD3 & 0.159 & 0.109 & 0.119 \\
\hline
\end{tabular}

NC, negative control; KD, knockdown.

demonstrated that the migratory ability of the KD cells was significantly reduced compared with that of control cells $(\mathrm{P}<0.05$; Figure 8).

\section{The effect of $D A B 2 I P$ silencing on the invasive ability of $S C L-1$ cells in vitro}

Cell invasive ability was evaluated with a Matrigel assay. The results demonstrated that the number of cells that penetrated the artificial basement membrane in the KD group was significantly lower than that in the control group
$(\mathrm{P}<0.05$; Figure 9).

\section{Discussion}

Due to the significant risk of recurrence and metastasis in cSCC, there is a strong necessity to discover novel molecules from various biological sources that may explain the occurrence and evolution of this keratinocyte-derived tumor.

For the first time, this study demonstrated that the expression of DAB2IP in cSCC tissues was upregulated 
Table 5 Statistical difference of the DAB2IP gene knockout rate between the KD group and NC group

\begin{tabular}{lccc}
\hline Sample & Average $\left(2^{-\Delta \Delta C t}\right)$ & STDEV & Knockdown efficiency \\
\hline NC & 1.005 & 0.004 & 0.524 \\
KD1 & 0.476 & 0.063 & 0.557 \\
KD2 & 0.443 & 0.073 & 0.871 \\
KD3 & 0.129 & 0.026 & \\
P value (NC vs. KD1) & 0.0045 & & \\
P value (NC vs. KD2) & 0.0054 & & \\
P value (NC vs. KD3) & 0.0002 & & \\
\hline
\end{tabular}

$\mathrm{NC}$, negative control; KD, knockdown.
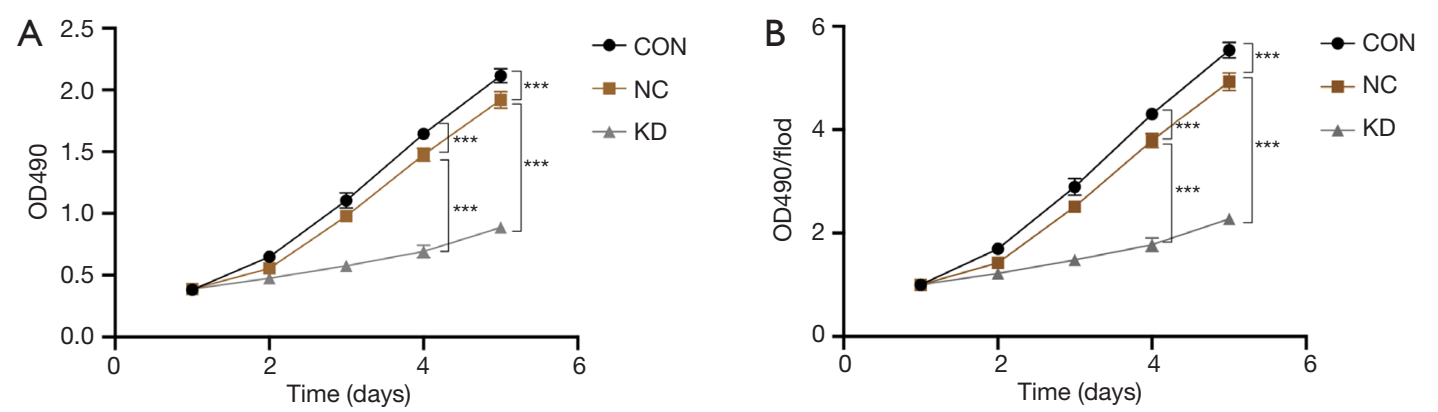

Figure 3 DAB2IP knockdown affected SCL-1 cell viability and phase. OD490 reflects the number of energetic cells. The changes in the absorption rate of the wavelength $490 \mathrm{~nm}$ light by the enzyme marker in the KD and control groups were compared over time. (A) Represents a comparison of the absorption of $490 \mathrm{~nm}$ light with time in the $\mathrm{KD}$ and control groups. (B) Represents a comparison of the time-varying multiple of light absorption at $490 \mathrm{~nm}$ between the $\mathrm{KD}$ and control groups. DAB2IP, disabled homolog 2-interacting protein; CON, control; NC, negative control group; KD, knockdown of DAB2IP; OD, optical density. ${ }^{* * *}, \mathrm{P}<0.001$.

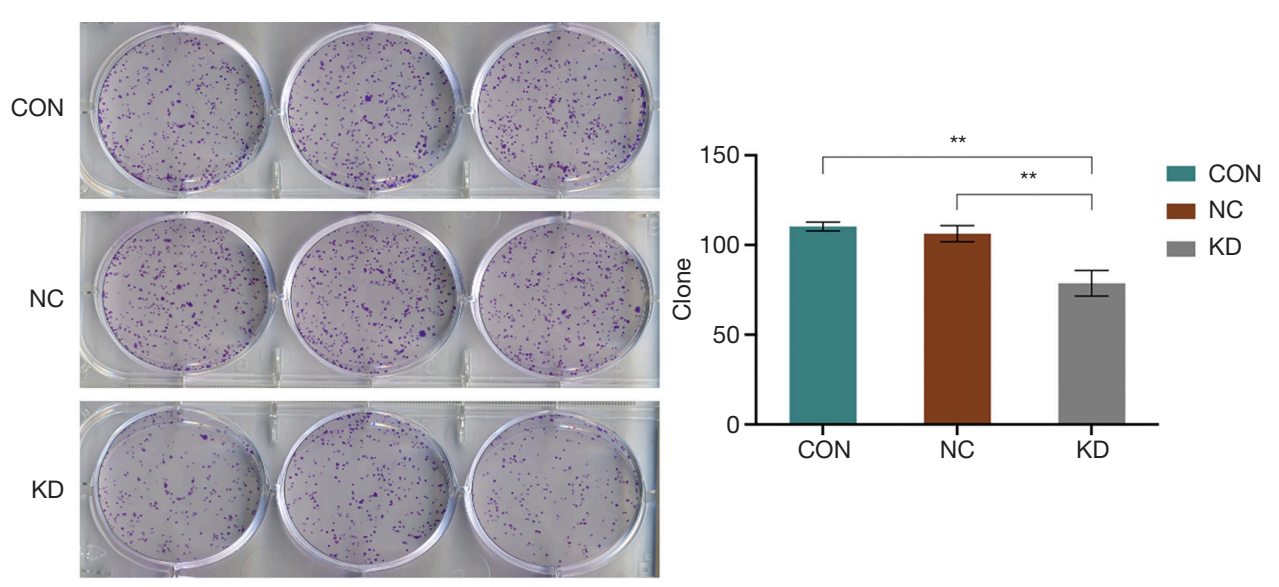

Figure 4 DAB2IP knockdown inhibited colony formation in SCL-1 cells. Comparison of the number of clones in each experimental group. Left, Giemsa stain. Magnification, $\times 1$. Knockdown of DAB2IP inhibited SCL-1 cell colony formation in vitro. Cells were cultured for 15 days and stained with Giemsa solution, and colonies containing $>50$ cells were counted manually. Representative photographs are presented, and the number of colonies was counted. The data were quantified and presented as the mean \pm SEM of three independent experiments. DAB2IP, disabled homolog 2-interacting protein; CON, control; NC, negative control group; KD, knockdown of DAB2IP. **, $\mathrm{P}<0.01$. 

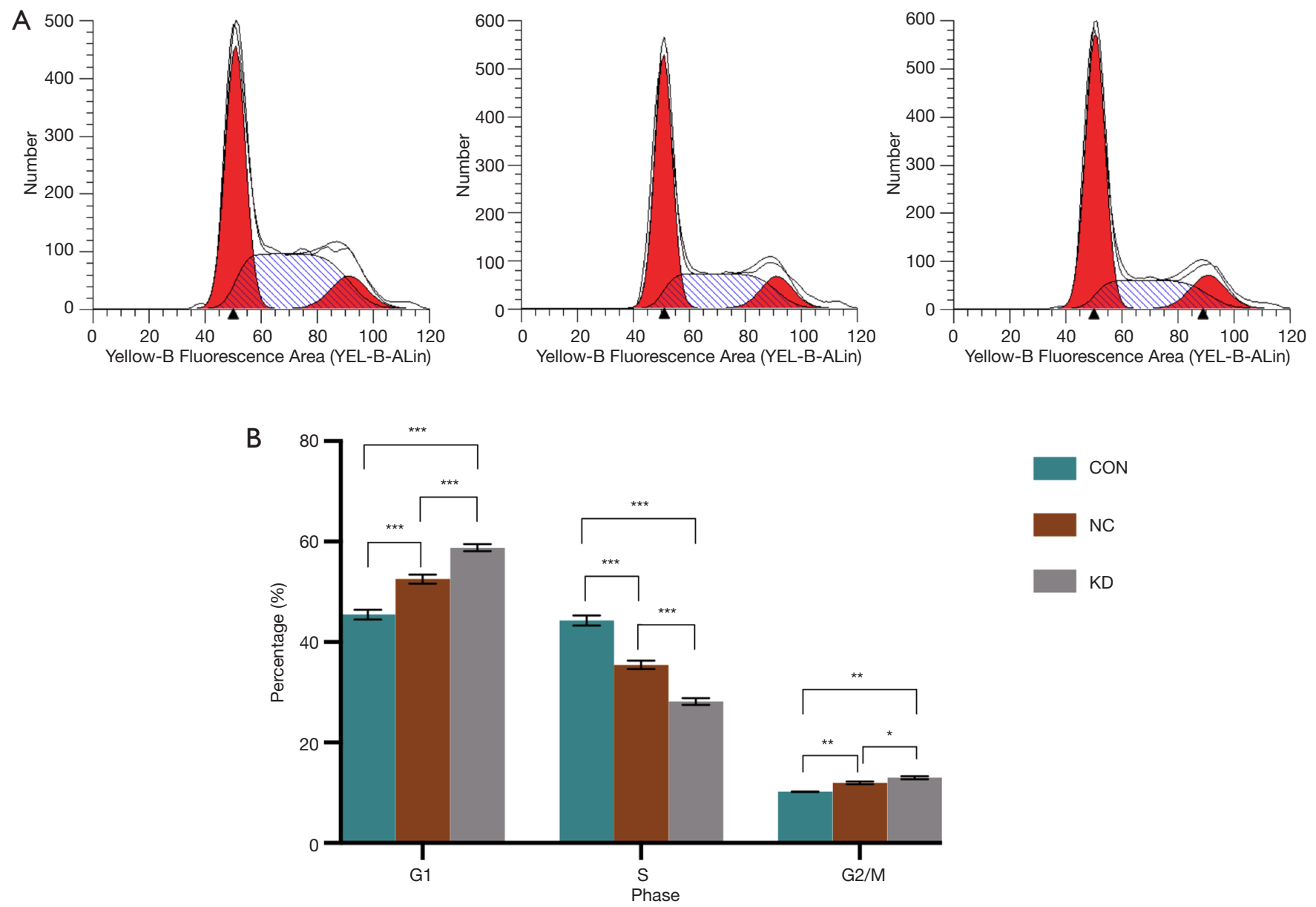

Figure 5 DAB2IP knockdown reduced the speed of genome replication. (A) Flow cytometry was used to detect the fluorescence intensity of propidium iodide, which was proportional to the content of nucleic acid embedded. (B) After 5 days of culture, the percentages of cells in the KD group at G1, S, and G2/M stages were compared with those in the control groups. Knockdown of DAB2IP inhibited DNA synthesis in SCL-1 cells. DAB2IP, disabled homolog 2-interacting protein; CON, control; NC, negative control group; KD, knockdown of DAB2IP. *, $\mathrm{P}<0.05 ;{ }^{* *}, \mathrm{P}<0.01 ;{ }^{* * *}, \mathrm{P}<0.001$.

compared with that in benign dermal vegetation. Furthermore, our results demonstrated that the knockdown of DAB2IP inhibited the proliferation, migration, and invasion of cSCC cells. Owing to the depth of infiltration in the majority of invasive cSCCs, DAB2IP is highly expressed; however, it is weakly expressed in superficial cSCCs.

The etiology of cSCC is associated with the following factors: ultraviolet irradiation; the reflective line of radiation or thermal radiation damage; chemical carcinogens, such as arsenic and polycyclic aromatic hydrocarbons; viral infections, particularly human papillomavirus (type 16, 18, 30 and 33); precancerous skin lesions, such as helicokeratosis and mucosal white spots; chronic skin diseases, such as chronic ulcers; chronic osteomyelitis and atrophic sclerosing moss; and genetic factors, including pigmented dry skin disease and albinism (14). Among the 48 patients enrolled in the present study, 27 were of a lower clinical stage (stage I-II; 56.25\%, 27/48), including 14 patients who exhibited high expression of DAB2IP $(51.9 \%, 14 / 27)$, while 20 patients with a higher clinical stage (stage III-IV) exhibited high expression of DAB2IP (95.2\%, 20/21). These findings suggest that patients with a high expression of DAB2IP may have a higher degree of tumor malignancy. No significant association was identified between the expression of DAB2IP and sex, tumor size, location, or clinical phenotype of cSCC. The average age of the 48 patients was 66 years, and the results of IHC analysis 
A
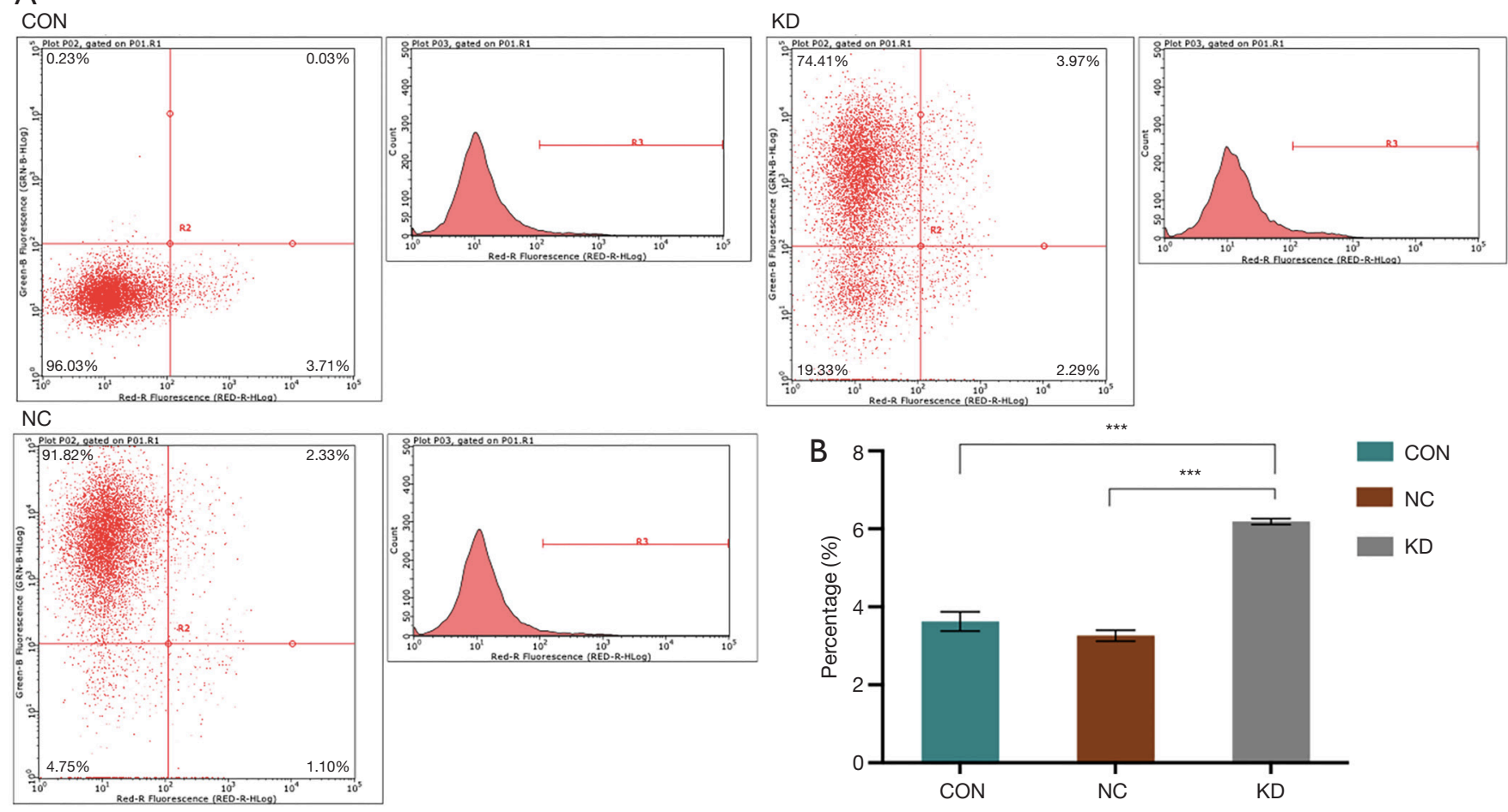

Figure 6 DAB2IP knockdown promoted apoptosis in SCL-1 cells. (A) Comparison of apoptosis rates between KD and control groups after 5 days of culture. Annexin V/allophycocyanin staining was performed to detect the apoptotic rate in vitro. Knockdown of DAB2IP promoted apoptosis in SCL-1 cells. (B) The relative number of early apoptotic cells was counted. The data were quantified and presented as the mean \pm SEM of three independent experiments. Statistical significance was determined by one-way ANOVA. DAB2IP, disabled homolog 2-interacting protein; CON, control; NC, negative control group; KD, knockdown of DAB2IP. ${ }^{* * *}, \mathrm{P}<0.001$.

demonstrated that the expression pattern of DAB2IP in squamous cell carcinoma tissue was higher in patients under the age of 66 years compared with older patients, which may be explained by young patients having a more robust overall metabolism than older patients. However, the relatively low number of cases, limited region of tissue collection (Guangdong province), and the potential effects of specimen storage may have affected the accuracy of these comparisons. The error may also have resulted from the differences in the location of the tissue material.

Analyzing differences between normal, inflammatory, and malignant keratinocyte proteomes may facilitate the discovery of novel biomarkers that may be used for early detection, risk assessment, and tumor monitoring in SCC in the future. Furthermore, the identification of novel potential biomarkers for SCC development and progression may aid in the discovery of individualized targeted therapies for patients with SCC. A previous study reported that DAB2IP is associated with the invasion and metastasis of prostate cancer (15), and it is possible that DAB2IP also serves a role in suppressing the proliferation and invasion of cSCC cells. Cell proliferation and invasion assays were performed to investigate the effects of DAB2IP depletion on the behaviors of SCL-1 cells in vitro.

To inhibit DAB2IP gene expression in the present study, the lentiviral vector DAB2IP-RNAi was used to interfere with SCL-1 cells. The results demonstrated that the knockdown of DAB2IP resulted in a decrease in the proliferative ability, as well as the migration and invasion rates, in SCL-1/DAB2IP-RNAi cells compared with the control cells; in contrast, the apoptotic rate in $\mathrm{KD}$ cells was higher than that in the control cells. These findings suggest that DAB2IP may promote the proliferation, migration, and invasion of cSCC cells in vitro. Through inducing cellular DNA replication in the $\mathrm{S}$ phase and inhibiting apoptosis in cSCC, DAB2IP may be a potent growth promoter. Knockdown of DAB2IP was shown to enhance gastric cancer cell growth and metastasis in vitro and to promote 

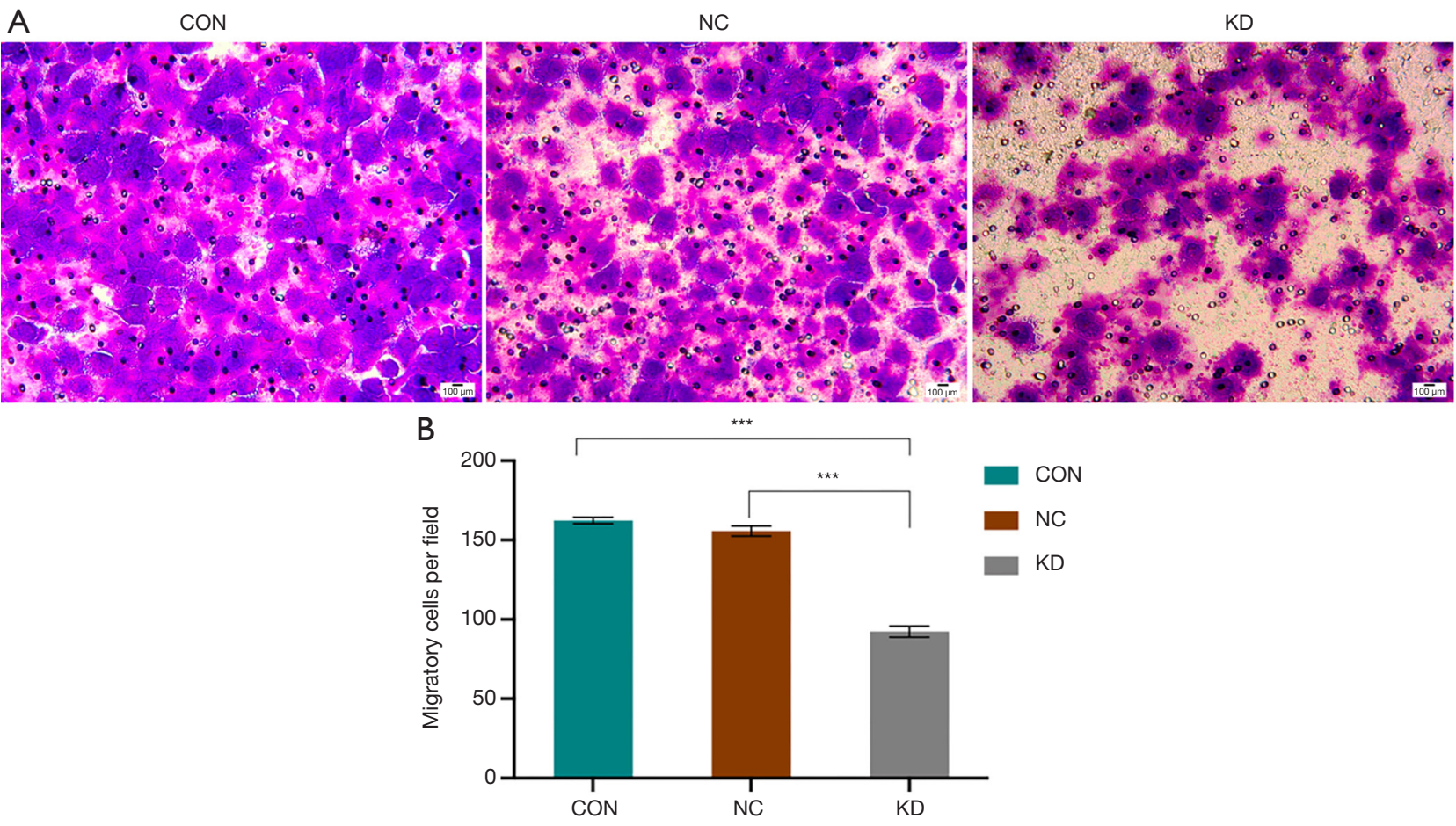

Figure 7 DAB2IP knockdown reduced the migratory ability of SCL-1 cells. (A) Giemsa staining. Magnification, ×200. Migration assays were performed in wild-type cells and in cells with stable knockdown of DAB2IP. Representative photographs are presented, and the relative number of migrated cells was counted. (B) The data were quantified and presented as the mean \pm SEM of three independent experiments. Statistical significance was determined by one-way ANOVA. DAB2IP, disabled homolog 2-interacting protein; CON, control; NC, negative control group; KD, knockdown of DAB2IP. ***, $\mathrm{P}<0.001$.

EMT progression at the protein and mRNA levels (16). In hepatocellular carcinoma cells, the silencing of DAB2IP has been demonstrated to increase proliferation and resistance to apoptosis (17). Epithelial-mesenchymal transition (EMT) has been implicated in promoting carcinoma invasion and metastasis, and the loss of DAB2IP expression has been shown to initiate EMT $(18,19)$. The high expression of DAB2IP in cSCC tissues and the effect observed after DAB2IP depletion in the present study contrast with these other reports on DAB2IP in various cancers. Such differences may stem from the fact that the prostate, liver, and stomach are internal organs of the human body, whereas the skin is the most superficial organ of the human body and originates from a different layer of the embryo; therefore, the effects of DAB2IP may be organ- or tissueselective.

The majority of studies on DAB2IP have been conducted in prostate cancer, in which a low expression of DAB2IP has been demonstrated to affect proliferation, survival, apoptosis, and EMT via several signaling pathways, including Ras-ERK, apoptosis signal-regulated kinaseJNK, and PI3K-Akt $(15,20,21)$. DAB2IP downregulation in various cancers results from the aberrant epigenetic regulation of its promoter due to DNA hypermethylation and/or histone modification by a histone methyltransferase $(8,22)$. A previous study showed that miR-889 binds to nucleotides 1,958-1,964 of the DAB2IP 3'-untranslated region and inhibits its expression, in turn inhibiting the Ras pathway, leading to the enhanced proliferation of esophageal squamous cell carcinoma cells (23). However, the present study lacks such evidence.

The results of the present study suggested that DAB2IP may be a valuable marker for the malignant development of cSCC. DAB2IP knockdown suppressed the proliferation, migration, and invasion of cSCC cells in vitro. This observation may assist with unearthing a novel treatment method for cSCC based on targeting of the DAB2IP signaling axis. However, there are some limitations to the present study. First, the effects of DAB2IP upregulation on cSCC tumorigenesis and metastasis were not investigated 



Figure 8 DAB2IP knockdown inhibited SCL-1 cell mobility and healing capacity. Migration rates were defined according to the wound size relative to $0 \mathrm{~h}$. The assays were performed in wild-type cells and in cells with stable knockdown of DAB2IP. (A) Representative photographs are presented, and the relative number of migrated cells was counted. (B) The data were quantified and presented as the mean \pm SEM of three independent experiments. Statistical significance was determined by one-way ANOVA. DAB2IP, disabled homolog 2-interacting protein; CON, control; NC, negative control group; KD, knockdown of DAB2IP. **, $\mathrm{P}<0.01$.
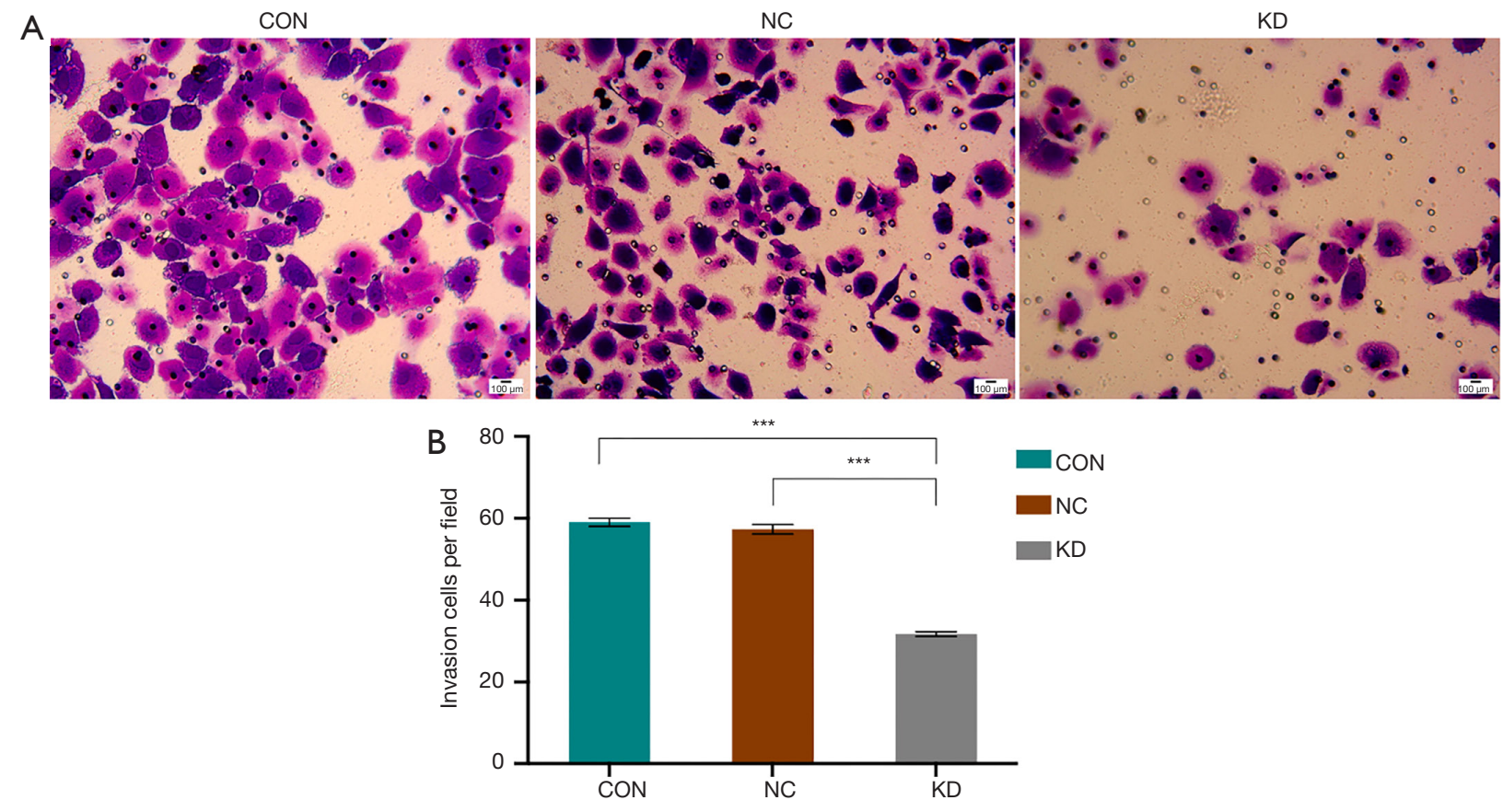

Figure 9 DAB2IP knockdown inhibited SCL-1 cell invasiveness. (A) Giemsa staining. Magnification, $\times 100$. Invasion assays were performed in wild-type cells and in cells with stable knockdown of DAB2IP. Representative photographs are presented, and the relative number of invading cells was counted. (B) The data were quantified and presented as the mean \pm SEM of three independent experiments. Statistical significance was determined by one-way ANOVA. DAB2IP, disabled homolog 2-interacting protein; CON, control; NC, negative control group; KD, knockdown of DAB2IP. ***, $\mathrm{P}<0.001$. 
in vitro. Second, while the role of EMT in tumor metastasis during cancer progression is known, the effects of DAB2IP on EMT progression or the mechanism for DAB2IP in the regulation of cSCC were not explored. Thus, more research should be undertaken to further investigate the functions of DAB2IP in cSCC.

\section{Acknowledgments}

Funding: This study was supported by the Guangdong Natural Science Foundation (grant no. 2015A030313685).

\section{Footnote}

Reporting Checklist: The authors have completed the MDAR reporting checklist. Available at http://dx.doi.org/10.21037/ atm-20-5067

Data Sharing Statement: Available at http://dx.doi. org/10.21037/atm-20-5067

Conflicts of Interest: All authors have completed the ICMJE uniform disclosure form (available at http://dx.doi. org/10.21037/atm-20-5067). The authors have no conflicts of interest to declare.

Ethical Statement: The authors are accountable for all aspects of the work in ensuring that questions related to the accuracy or integrity of any part of the work are appropriately investigated and resolved. The study was approved by the Guangdong Second Provincial General Hospital Ethical Committee (approval no. 2019-PFKWZ-004). All procedures performed in this study involving human participants were in accordance with the Declaration of Helsinki (as revised in 2013). All patients signed informed consent for surgery when sample collection took place. All patients agreed for their samples to be used in scientific research.

Open Access Statement: This is an Open Access article distributed in accordance with the Creative Commons Attribution-NonCommercial-NoDerivs 4.0 International License (CC BY-NC-ND 4.0), which permits the noncommercial replication and distribution of the article with the strict proviso that no changes or edits are made and the original work is properly cited (including links to both the formal publication through the relevant DOI and the license). See: https://creativecommons.org/licenses/by-nc-nd/4.0/.

\section{References}

1. Pyczek J, Khizanishvili N, Kuzyakova M, et al. Regulation and Role of GLI1 in Cutaneous Squamous Cell Carcinoma Pathogenesis. Front Genet 2019;10:1185.

2. Migden MR, Rischin D, Schmults CD, et al. PD-1 Blockade with Cemiplimab in Advanced Cutaneous Squamous-Cell Carcinoma. N Engl J Med 2018;379:341-51.

3. Cañueto J. Implementation of staging systems in clinical practice for cutaneous squamous cell carcinoma. Ann Transl Med 2019;7:S51.

4. Riihila P, Nissinen L, Knuutila J, et al. Complement System in Cutaneous Squamous Cell Carcinoma. Int J Mol Sci 2019;20:3550.

5. Nehal KS, Bichakjian CK. Update on Keratinocyte Carcinomas. N Engl J Med 2018;379:363-74.

6. Kong Z, Raghavan P, Xie D, et al. Epothilone B confers radiation dose enhancement in DAB2IP gene knock-down radioresistant prostate cancer cells. Int J Radiat Oncol Biol Phys 2010;78:1210-8.

7. Chen H, Pong RC, Wang Z, et al. Differential regulation of the human gene DAB2IP in normal and malignant prostatic epithelia: cloning and characterization. Genomics 2002;79:573-81.

8. Chen S, Wang L, Yao B, et al. miR-1307-3p promotes tumor growth and metastasis of hepatocellular carcinoma by repressing DAB2 interacting protein. Biomed Pharmacother 2019; 117:109055.

9. Duan Y, Yin X, Lai X, et al. Upregulation of DAB2IP Inhibits Ras Activity and Tumorigenesis in Human Pancreatic Cancer Cells. Technol Cancer Res Treat 2020;19:1533033819895494.

10. Ni QF, Zhang Y, Yu JW, et al. miR-92b promotes gastric cancer growth by activating the DAB2IP-mediated PI3K/ AKT signalling pathway. Cell Prolif 2020;53:e12630.

11. Vasconcelos L, Melo JC, Miot HA, et al. Invasive head and neck cutaneous squamous cell carcinoma: clinical and histopathological characteristics, frequency of local recurrence and metastasis. An Bras Dermatol 2014;89:562-8.

12. Fromowitz FB, Viola MV, Chao S, et al. ras p21 expression in the progression of breast cancer. Hum Pathol 1987;18:1268-75.

13. Pfaffl MW. A new mathematical model for relative quantification in real-time RT-PCR. Nucleic Acids Res 2001;29:e45.

14. Lauritsen JM, editor. EpiData Classic, Data Management 
and basic Statistical Analysis System. Odense Denmark, EpiData Association, 2000-2008. Available online: http:// www.epidata.dk

15. Xie D, Gore C, Liu J, et al. Role of DAB2IP in modulating epithelial-to-mesenchymal transition and prostate cancer metastasis. Proc Natl Acad Sci U S A 2010;107:2485-90.

16. Sun L, Yao Y, Lu T, et al. DAB2IP Downregulation Enhances the Proliferation and Metastasis of Human Gastric Cancer Cells by Derepressing the ERK1/2 Pathway. Gastroenterol Res Pract 2018;2018:2968252.

17. Calvisi DF, Ladu S, Conner EA, et al. Inactivation of Ras GTPase-activating proteins promotes unrestrained activity of wild-type Ras in human liver cancer. J Hepatol 2011;54:311-9.

18. Yang J, Weinberg RA. Epithelial-mesenchymal transition: at the crossroads of development and tumor metastasis. Dev Cell 2008;14:818-29.

19. Wang J, Ding Y, Liang L. The function and molecular

Cite this article as: Yuan SP, Li CX, Qin S, Wen J, Zhang XB, Tian X, Zhu CY, Li T, Huang JP, Zheng XH. High expression of disabled homolog 2-interacting protein contributes to tumor development and proliferation in cutaneous squamous cell carcinoma. Ann Transl Med 2020;8(18):1131. doi: 10.21037/ atm-20-5067 mechanisms of DAB2IP in invasion and metastasis of colorectal cancer; Southern Medical University, 2014.

20. Dai X, North BJ, Inuzuka H. Negative regulation of DAB2IP by Akt and SCFFbw7 pathways. Oncotarget 2014;5:3307-15.

21. Xie D, Gore C, Zhou J, et al. DAB2IP coordinates both PI3K-Akt and ASK1 pathways for cell survival and apoptosis. Proc Natl Acad Sci U S A 2009;106:19878-83.

22. Zhang X, Li N, Li X, et al. Low expression of DAB2IP contributes to malignant development and poor prognosis in hepatocellular carcinoma. J Gastroenterol Hepatol 2012;27:1117-25.

23. $\mathrm{Xu} \mathrm{Y,} \mathrm{He} \mathrm{J,} \mathrm{Wang} \mathrm{Y,} \mathrm{et} \mathrm{al.} \mathrm{miR-889} \mathrm{promotes} \mathrm{proliferation}$ of esophageal squamous cell carcinomas through DAB2IP. FEBS Lett 2015;589:1127-35.

(English Language Editor: J. Reynolds) 